\title{
CONFIRMATION OF A THEORY: RECONSTRUCTION OF AN ALLUVIAL PLAIN DEVELOPMENT IN A FLUME EXPERIMENT
}

\author{
László Bertalan, Csaba Albert Tóth, Gergely Szabó, Gábor Nagy, \\ FrantišEK KudA and SZILÁRd SZABÓ \\ With 9 figures \\ Received 06 July $2015 \cdot$ Accepted 07 July 2016
}

\begin{abstract}
Summary: Fluvial geomorphologists have tried to describe the outstanding tectonically affected avulsion process of Tisza River at the Great Hungarian Plain by various theoretical concepts. Flume experiments provide the ability to examine the main characteristic processes of a highlighted surface development theory under controlled settings within an accelerated time scale. Our goal was to reconstruct and refine these hypotheses from a new experimental point of view. Contrary to the previous flume studies focused on a highlighted mechanism, our experiment combined several processes for confirmation purposes. In this study we performed an experiment of the avulsion process mentioned above on a $12 \times 5 \times 2.5 \mathrm{~m}$ flume where a special instrument was planted under the sand layers in order to simulate the vertical tectonic movements. A terrestrial laser scanner was used to record the different stages of the topographic evolution. We shaped the initial surface and executed the main landscape forming processes according to theoretical descriptions then with modifications to examine the similarities and differences between the experimental outcomes and the theoretical evolution. The results of three different types of scenarios proved the key role of the uplifting Nyírség alluvial fan in the channel direction changing process of Tisza River. On the other hand, the role of Bodrogköz area had been questioned. Flume experiments with appropriate equipment can serve as a suitable tool for the reconstruction of surface development theories taking into account several landscape forming processes simultaneously.
\end{abstract}

Zusammenfassung: Die außergewöhnliche, tektonisch bedingte Flussverlagerung der Theiß in der Großen Ungarischen Tiefebene beschäftigt die Fluvialmorphologie seit Langem und hat zu unterschiedlichen theoretischen Erklärungsansätzen geführt. Experimente in Versuchskanälen bieten die Möglichkeit, grundlegende Prozesse der Fluss- und Oberflächengenese einzelner theoretischer Ansätze unter kontrollierten und zeitlich beschleunigten Bedingungen zu untersuchen. Das Ziel der vorliegenden Studie bestand darin, die Hypothesen der Theiß Flussverlagerung von einer experimentellen Seite aus zu beleuchten. Angesicht der Komplexität der vorliegenden theoretischen Konzepte, bestand im Unterschied zu zahlreichen anderen Versuchskanalexperimenten, die Herausforderung dieser Studie in der Simulation eines multifaktoriellen Prozessgefüges. Die Experimente wurden in einem 12 × 5 × 2,5 m Versuchskanal durchgeführt, der durch einem Umbau so modifiziert wurde, dass unterschiedliche Zonen angehoben und abgesenkt werden können, um tektonische Bewegungen zu simulieren. Unterschiedliche Stadien der Oberflächengenese wurden mit einem terrestrischen Laserscanner erfasst. Ausgehend von einer initialen Oberfläche und wurden die Experimente entsprechend der theoretischen Konzepte durchlaufen und für Vergleichszwecke ergänzt durch Versuchsläufe mit leicht modifizierten Rahmenbedingungen. Im Ergebnis belegen die durchgeführten Experimente übereinstimmend die besondere Rolle von Hebungsprozessen der Nyírség Region für die Flussverlagerung der Theiß. Im Gegensatz zu vorliegenden theoretischen Erklärungsansätzen konnte allerdings die Bedeutung tektonischer Prozesse im Bodrogköz Gebiet nicht belegt werden. Anhand der vorliegenden Studie konnte aufgezeigt werden, dass sich technisch entsprechend angepasste Versuchskanäle auch für die experimentelle Analyse komplexer fluvialmorphologischer Fragestellungen eignet.

Keywords: Fluvial geomorphology, flume experiment, alluvial fan, avulsion, Tisza River, terrestrial laser scanner, Hungary

\section{Introduction}

Geomorphological investigations, especially in fluvial geomorphology, have always been based on various field surveys with the purpose of examining landforms, processes and their driving factors at their specific geographical location (SLAYMAKER
1991; THORnDyCRAFT et al. 2008). Increasingly, experimental geomorphological methods have been applied, as scientists realized its benefits (Williams 1971; Schumm et al. 1987; PaOla et al. 2009). The main purpose of the experimental geomorphologists is to give analytical explanations for fundamental geomorphic questions, since exact processes cannot be 
observed directly. In laboratory conditions with the use of specially designed apparatuses, the reproduction of fluvial surface development processes could play a key role in both the creation and the clarification of theoretical concepts (Peakall et al. 1996).

Hardware simulation facilities (e.g. river modeling flumes, hydraulic flumes, stream tables, sand tables, sand boxes, plotting boards) allow precise experiments that can be controlled and reproduced in order to perform different scenarios for a concrete fluvial process (Schumm et al. 1987). The compression of the spatial and temporal scales makes it possible to observe landform development otherwise impossible to observe directly in the field (McKenNA Neuman et al. 2013). Moreover, experimental manipulation is also ensured; thus, the effect of several driving variables can be simulated in a selected range (e.g. Ackers 1964; Lisle et al. 1991; Bennett and BRIDGe 1995; VAN DijK et al. 2012).

Since the early experiments of GilberT (1914) hydraulic flumes have been operated by flow and sediment supply similar to natural rivers; however, such factors as e.g. sidewall roughness, shape of bank or-, slope differs from conditions that can be found at the surface. Small-scale experiments on meandering and river morphology were introduced for the first time by FRIEDKIN (1945) and later LEOPOLD and Wolman (1957). During the 1960s and 1970s numerous fluvial laboratory facilities were developed on the basis of cooperation of river engineers and fluvial geomorphologists (e.g. KÁDÁr et al. 1957; KINOSHITA 1957; Wolman and Brush 1961; Ackers 1964; GuY et al. 1966; Hickin 1972; Schumm and KHAN 1972). Moreover, many study areas in fluvial geomorphology, including meandering channels (SмITH 1998; Peakall et al. 2007; Rüther and Olsen 2007; Termini and Piraino 2011; Van Dijk et al. 2012), meander cutoffs (LE Coz et al. 2010), braided channels (Egozi and Ashmore 2009; Pirkhoffer et al. 2014), drainage systems (Douglass and SchmeECKLE 2007), point bar development (LisLe et al. 1991; Lanzoni 2000), delta development (Muto and Steel 2001, 2004; Pirkhoffer et al. 2014), valley development (MArra et al. 2014) or landslides (Okura et al. 2002), have been studied using experimental approaches.

Beyond investigations focused on the subject of rivers, other indirect surface development processes, such as the formation of alluvial fans in the vicinity of mountainous regions also need experimental explanations (HOOKE and ROHRER 1979; Parker et al. 1998). Flume based results associated with alluvial fans and deltas are proven solutions for demonstrating sediment transport (Whipple et al. 1998; Postma et al. 2008) and evolutional dynamics (VAn Dijk et al. 2009; Clarke et al. 2010) according to various impacts (VISERAS et al. 2003; Nicholas and Quine 2007a, b). Fluvial response to tectonic uplifts has been investigated from several aspects (e.g. OuCHi 1985; LAgue et al. 2003; Graveleau et al. 2011). Several studies have been focused on mathematical modeling involving physical parameters on these topics (e.g.; BEVEN and Kirkby 1979; Coulthard et al. 1999; 2002; HOWARD 1994), but all of them have concentrated on only a highlighted process in contrast with a multiple evolutionary approach.

The main concept of this study was to prove that flumes are suitable tools for modelling complex surface development processes and also to confirm mesoscale landscape development theories.

Accordingly, we combined several experimental approaches related to fluvial geomorphology: avulsion process, alluvial fan development, and tectonically affected vertical surface movements; unlike the research reported in the works listed above. Furthermore, a complex and remarkable avulsion at an alluvial section of the Hungarian Tisza River in the past has raised several questions and discussion between geomorphologists; thus, we attempted to examine it in a flume in order to refine and confirm it. With this study we intended to demonstrate the applicability of a flume for a multiple experimental model of a surface development theory.

\section{Theoretical background of the flume ex- periment}

The surface and fluvial system development of the Great Hungarian Plain (GHP), which is an intramountain basin in Hungary, has detailed theoretical description (BORSY and FÉlEGYHÁZI 1983; BORSY et al. 1989; BORSY 1995; GÁBRIS 1995, 2002; FÉlegyházi et al. 2004; Timár et al. 2005; VAss et al 2010; GÁbris and NÁdor 2007; Demeter et al. 2010, 2011; GÁBris et al. 2012; SzABÓ et al. 2012; Kiss et al. 2014).

At the northeastern part of the GHP the Tisza River and its tributaries, the Szamos River and the Paleo-Bodrog Rivers built an extensive alluvial fan called the Nyírség (Fig.1/A) (Borsy 1961, 1989, 1990). During the Pleistocene, the Tisza River flowed from the Carpathians through the Érmellék and reached the Danube River at the Körös Basin (Fig.1/A,B; GÁbris 1995; GÁBris and NÁdOR 2007). 

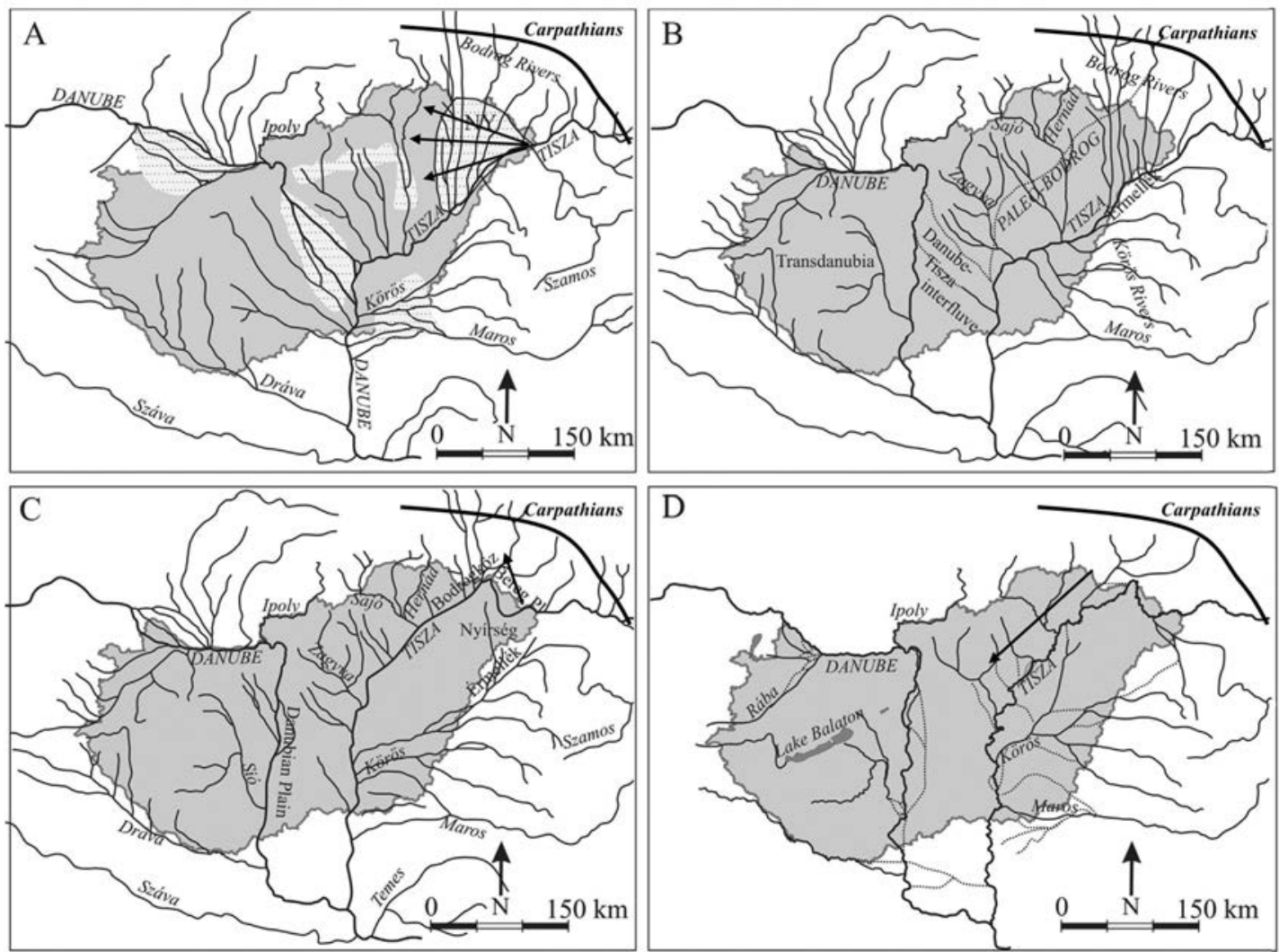

Fig. 1: Paleo-direction changes of the main Hungarian rivers during the Pleistocene. A: from Middle to Late Pleistocene (dotted areas indicate the major alluvial fans, NY - Nyírség Alluvial fan): B: beginning of the Weichselian. C: Late Weichselian. D: Holocene. Source: Somogyı, 1961; GÁbris and NÁdor 2007; Mezösı 2011; Kiss et al. 2014

The shifts up to $80-100 \mathrm{~km}$ in flow direction of the Tisza River are based on major and secondary subsiding - uplifting basins (e.g. Bodrogköz, Bereg Plain, Érmellék) driven by Quaternary tectonic processes (Timár et al. 2005; Kiss et al. 2014). Furthermore, some areas like the Nyírség had a lesser degree of subsidence than others; this process could be observed as a relative uplift. Later it started to uplift separately, emerging later as a divide (Borsy et al. 1989). The intensive subsidence of the Bodrogköz and the Bereg Plain started in the Upper Pleniglacial at ca. $22 \mathrm{ka}$ (BORsy et al. 1989) and their rate reached $0.33 \mathrm{~mm} / \mathrm{y}$ on average. However, it is suggested that sometimes this rate was up to $0.8 \mathrm{~mm} / \mathrm{y}$ (BORSY 1989; FÉLEGYHÁZI et al. 2004). A slight shifting of the Tisza River eastwards to the Érmellék occurred at the beginning of the Weichselian (Borsy 1989). As a result, the Tisza River assumed a higher position at the Nyírség alluvial fan; thus, the river started to slide from its central section (BORSY 1989); however, TimÁr et al. (2005) argue that there must have been an additional abrupt avulsion of the Tisza River.
The outstanding avulsion process of the Tisza River was suggested at ca. $20 \mathrm{ka}$ (Borsy et al. 1989), ca. 16-18 ka (Timár et al. 2005) and ca. 14 ka (GÁBris and NÁDOR 2007) when the Tisza was forced to turn northward and leave the Érmellék (Fig. 1/C) due to the intensive shifting period of Bodrogköz and the relative uplifting period of the Nyírség and the Érmellék (BORSY et al. 1989; GÁBRIS 2002; LÓKI and FÉlegyházi 2008; Demeter et al. 2010, 2011). When the Tisza River started to capture the rivers of the Paleo-Bodrog system, the Nyírség alluvial fan had been left without water supply from large rivers (Fig. $1 / \mathrm{D})$; thus, aeolian processes began in the dry areas after the fluvial processes had ended (LóKI et al. 1994; Kiss et al. 2012, 2014). Since the last glacial period, the fluvial system of the GHP including the Tisza River has been stable except for some minor avulsions (KIss et al. 2014) (see also Fig. 2). In this study we conducted flume experiments in order to reveal whether this approach can confirm the theoretical concepts. Accordingly, our flume setups were designed for comparing the theoretical and experimental avulsion processes on the paleo-Great 


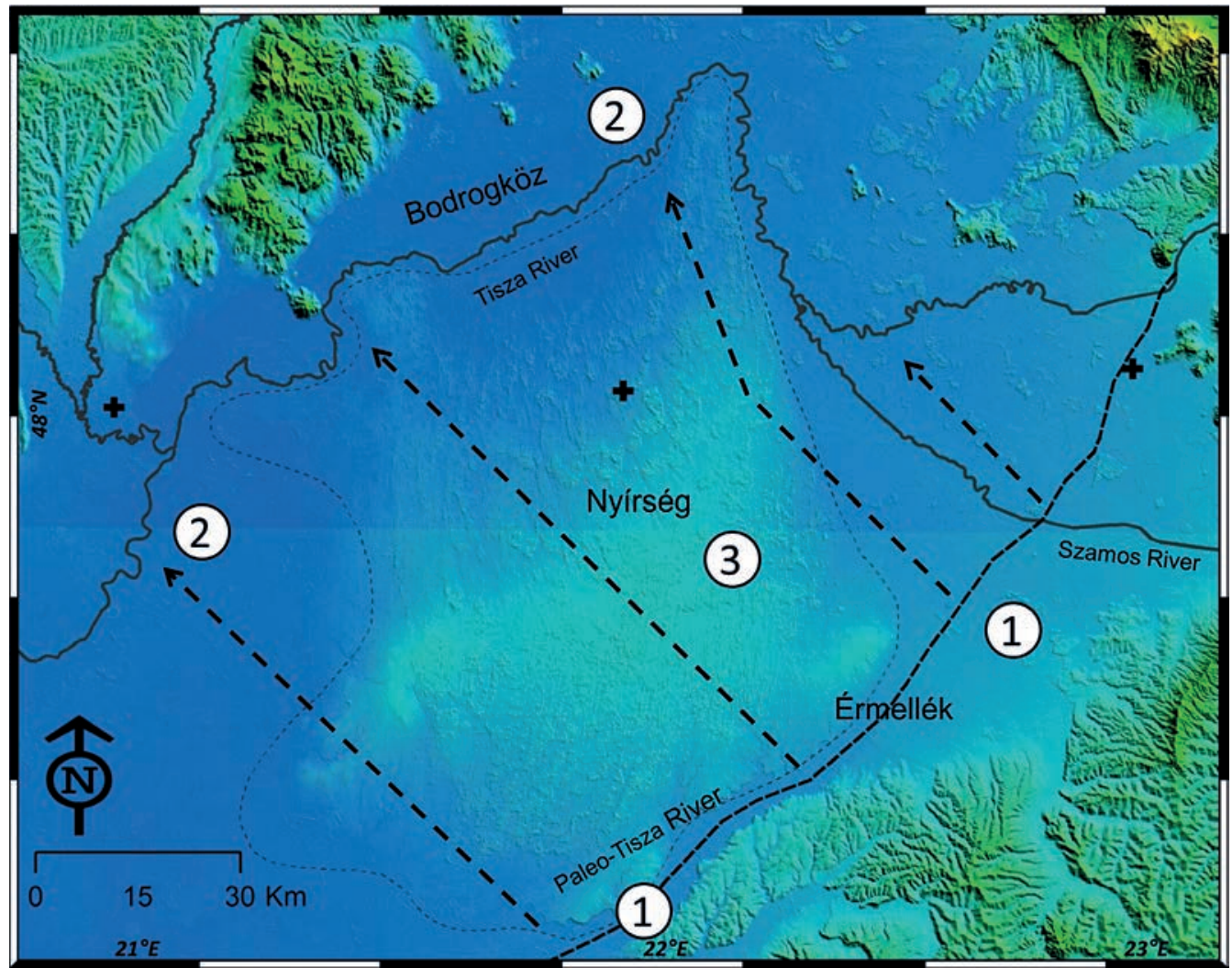

Fig. 2: The theoretical avulsion of the Tisza River (modified after TIMÁR et al. 2005) - topographic data: SRTM 1-Paleo-channel of the Tisza River, which switched from the Érmellék to the West to its present course; 2 - Present channel of the Tisza River after the avulsion next to the subsided Bodrogköz area; 3 - The elevated Nyírség alluvial fan area

Hungarian Plain. Our main goal was to prove that changes in flow direction were induced by vertical processes. The main question was whether changes in flow direction induced by vertical tectonic processes can be reconstructed.

\section{Materials and methods}

\subsection{Flume parameters}

Our experiments were held at our departmental fluvial laboratory that has a large flume which is a 12 meters long, 5 meters wide and 2.5 meters deep concrete-based basin (Fig. 3). It has a slight slope for the natural river runoff-processes and it is filled with sand on a $7 \mathrm{~m}$ long and $4 \mathrm{~m}$ wide area. Six taps had been planted in the margins (Fig. 3/1), which have their own water-meters; thus, the discharge of a flow can be precisely measured and we can set up rivers to any location in the flume using hose-pipes. Each flow and its discharge can be controlled to imitate the effects of climatic factors, flow regime or the flood periods, etc. A special instrument that can simulate tectonic movements was situated under the sediment layers and its operation was controlled by a compressor. Eight parts of the instrument could be raised and sunk by the compressor separately as well as the connected areas (Fig. 3).

\subsection{Concept of the experiment}

Our experimental perspective was to shape the surface of the flume considering the determining elements of the paleo-surface of the investigated area in order to replicate the natural processes and the theories describing them. Then we tried to simulate the surface development and the avulsion process of the Tisza River related to the theoretical concepts.

At the northeastern side of the flume, we accumulated a considerable amount of material to symbolize the North-Eastern Carpathians. We situated two main flows symbolizing the Tisza River and its tributary Szamos River at the topside of this elevated 


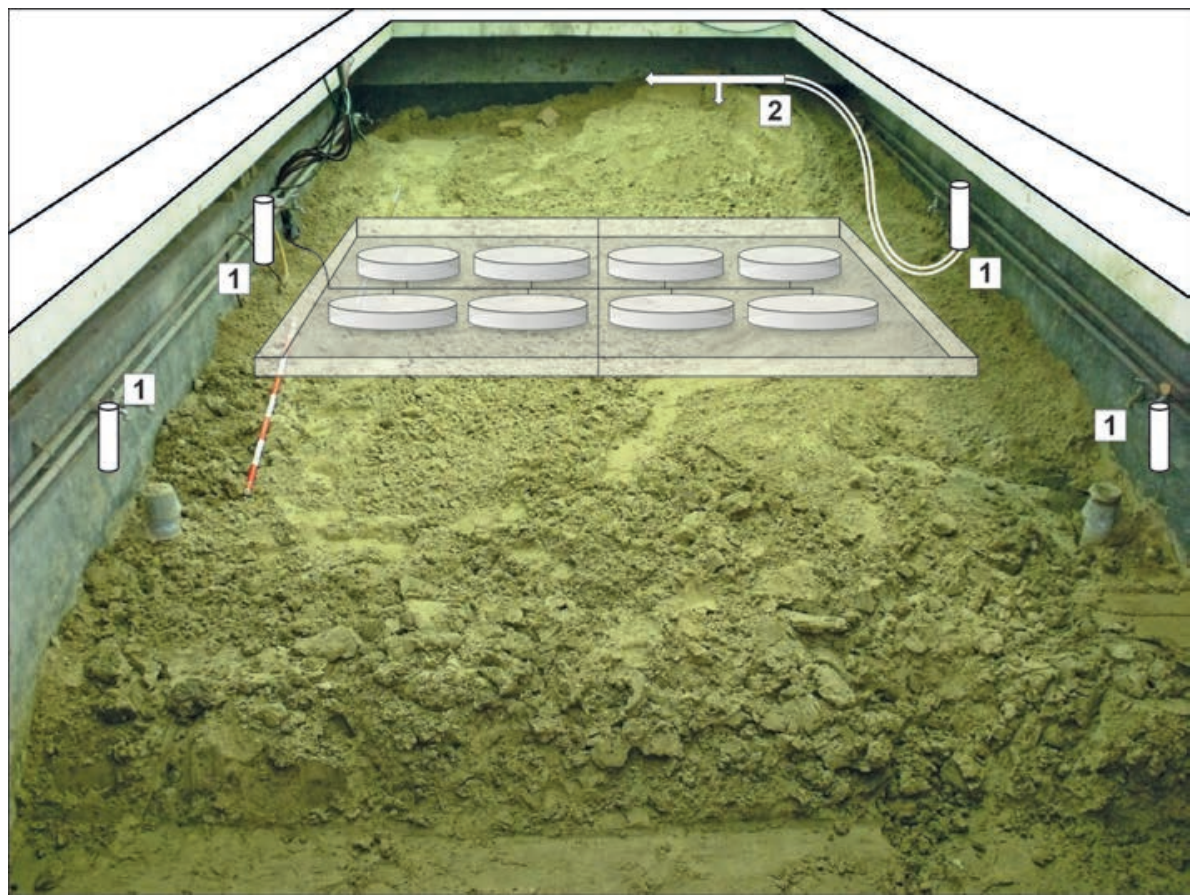

Fig. 3: Schematic view of the experimental flume. 1 - Water taps with water meters; $2-$ Hosepipes used for setting up the experimental flows to the appropriate location; 3 - Instrument for demonstrating the tectonic movements

surface. At the beginning of the experiment we did not use preformed river channels, since we wished to demonstrate an entire individual development of the flow direction. From this stage, the forming of a considerable alluvial fan like that of the Nyírség could be predicted at the base level with large amounts of material displacement and valley development from the top of the elevated surface. Following the alluvial fan development, our goals were to simulate the intensive shifting of the Bodrogköz and the uplifting process of the Nyírség using the tectonic instrument of the flume and, based on the theory, to observe the probability of the avulsion of the Tisza River according to these tectonic conditions.

With the purpose of focusing on the tectonically affected avulsion we set up a constant $0.2 \mathrm{l} / \mathrm{s}$ and $0.1 \mathrm{l} / \mathrm{s}$ discharge rate of flow symbolizing the Tisza River and Szamos River; thus, the climatic factors were excluded from the experiments. The discharge rates were scaled according to the estimations of GÁBRIs (1986). There was no sediment feed planted to the margin; thus, the running water scoured out the sand that was stored in the flume.

In order to verify the relationship between the theory and the experimental outcome of the theory-based scenario (Scenario \#1), we examined two modified scenarios as well, where the conditions had differed from the original theory. The second sce- nario was performed without the tectonic sinking of the Bodrogköz area in order to analyze its role in the avulsion process (Scenario \#2). Finally, in a third scenario, the alluvial fan of the Nyírség showed a moderate degree of sinking (Scenario \#3).

The geodetic survey of our scenarios were divided into three major stages. Every experiment stage lasted 15 minutes; however, each of them was paused during the surveying process in order to ensure the recording of a momentary state of the surface development. Each stage was investigated separately during the data processing. At the beginning an initial surface was shaped as it was described above. The second stage represents the alluvial fan development while the last stage refers to the processes of tectonic shifting/uplifting as well as the possible formation of avulsion on the Tisza River.

As a first step, we reconstructed the environmental conditions for each scenario (surface topography, discharge rate and tectonic movements), then we performed the experiment consecutively five times consecutively, to ensure that the final results could be repeated without significant change and that this did not occur by chance. As all repetitions resulted in the same outcome, we found it eligible for the survey.

A Leica ScanStation C10 terrestrial laser scanner (TLS) was used for collecting high precision $(<\mathrm{cm})$ digital surface models, as reference data for 
the experimental scenarios. These kinds of datasets allowed us to analyze the possible flow directions that could be formed according to the surface development processes during the experiment. The point cloud, generated by the TLS was processed and cleaned in a metric coordinate system using Leica Cyclone 7.3 software. Each survey of the experiment stages resulted in a point cloud with 2618 $\mathrm{x} 6284$ points. For the spatial analysis the point cloud was interpolated into elevation grid in Surfer 10. The chosen method was kriging, with $0.8 \mathrm{~cm}$ cell size. Spatial analysis (e.g. cross sections, flow directions) of the different surface models were performed in ArcGIS 10.3, Surfer 10 and SAGA GIS 2.1 (ConRad et al. 2015).

\section{Results}

We started the experiment from the initial surface (Fig. 4; Fig 5/A-D-G) where the two main flows of the Tisza and Szamos Rivers were positioned at the top of the elevated surface that corresponded to the Carpathians situated at the northeastern edge of the flume. On figure. 5/A-D-G we also illustrated the possible flow directions where two paths (which are connected to the flow-heads) were highlighted and could be maintained as the possible paths of the Tisza and Szamos Rivers.
According to theory, the Bodrogköz played a key role in the avulsion process of the Tisza River; hence, the representing model area has been uplifted prior to model runs in order to move it downward according to the different scenario description. The first stage of each scenario lasted 15 minutes with constant discharge without sediment supply.

During all of the scenarios the second stage resulted in a considerable amount of material displacement (Fig. 5/B-E-H). Both erosional and accumulation processes occurred along the experimental Tisza and Szamos Rivers and both flows generated V-shaped valleys at the steep slopes of the mountainous northern part of the flume (Fig. 4; Fig. 5; Fig. 6-7/S01-S05-S09).

The sediments transported from the elevated positions were accumulated at the plain region directly beside the slope of the mountainous region. At first, a single regular-shaped alluvial fan was formed by the two flows at the central and eastern part (corresponding to the Érmellék) of the flume (Fig. 4/B; Fig. 5/B-E-H). The cross-section analysis of the experiment stages (Fig. 6; Fig. 7) determined that the alluvial fan development caused an increase up to 10 $\mathrm{cm}$ in height compared to the initial surface in each scenario.

The process showed the typical characteristics of an alluvial fan development while the flows were continuously shifting their paths back and forth (5-
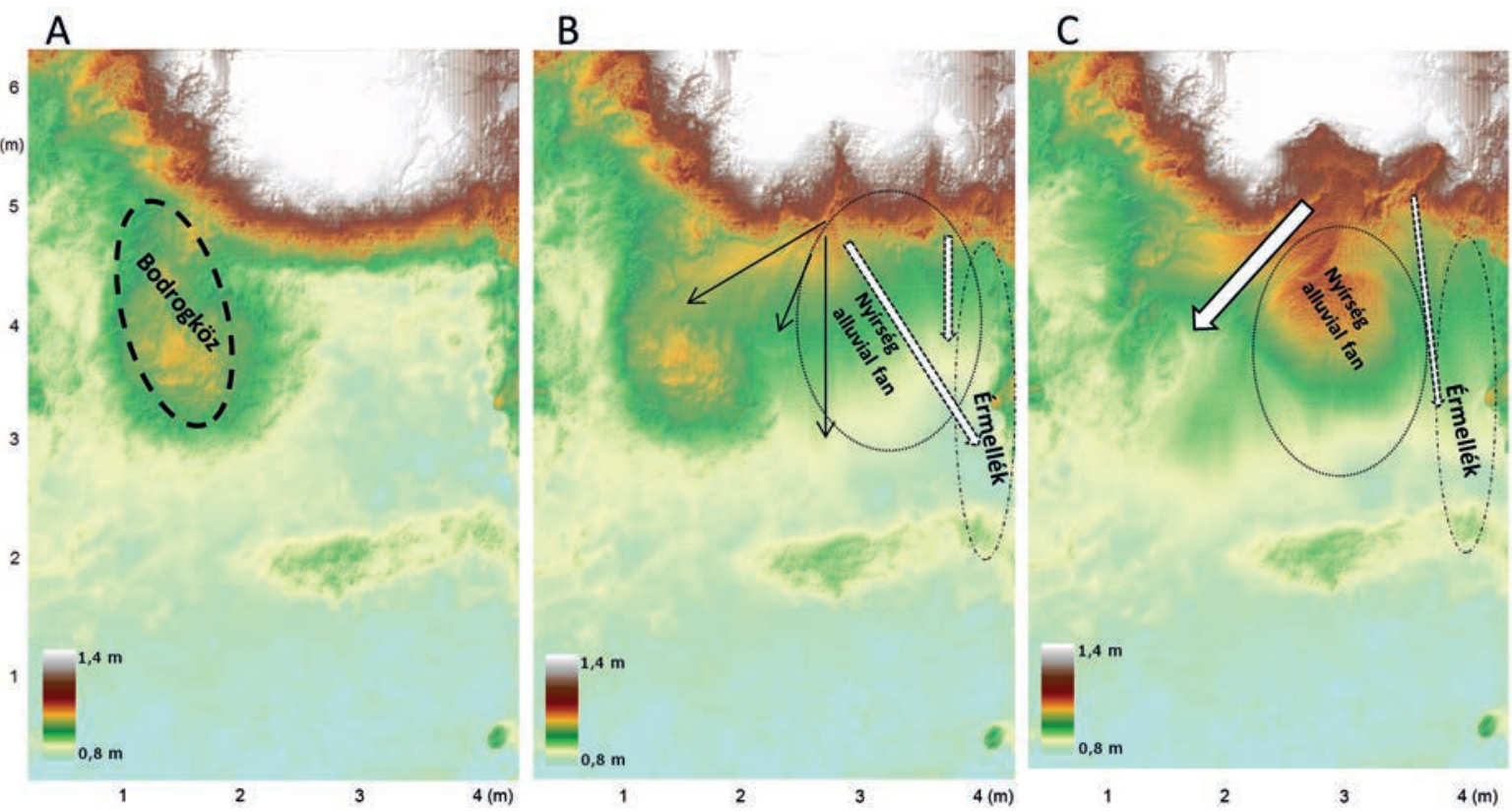

Fig. 4: The main processes during the experimental surface and flow evolution in Scenario \#1. The arrows represent the dominant flow directions during the experiment. A - Initial surface; B - Accumulation and alluvial fan development followed by the tectonic uplifts/shifts; C - Result of the experiment with the avulsion of the main flow; T-Tisza River; Sz - Szamos River 

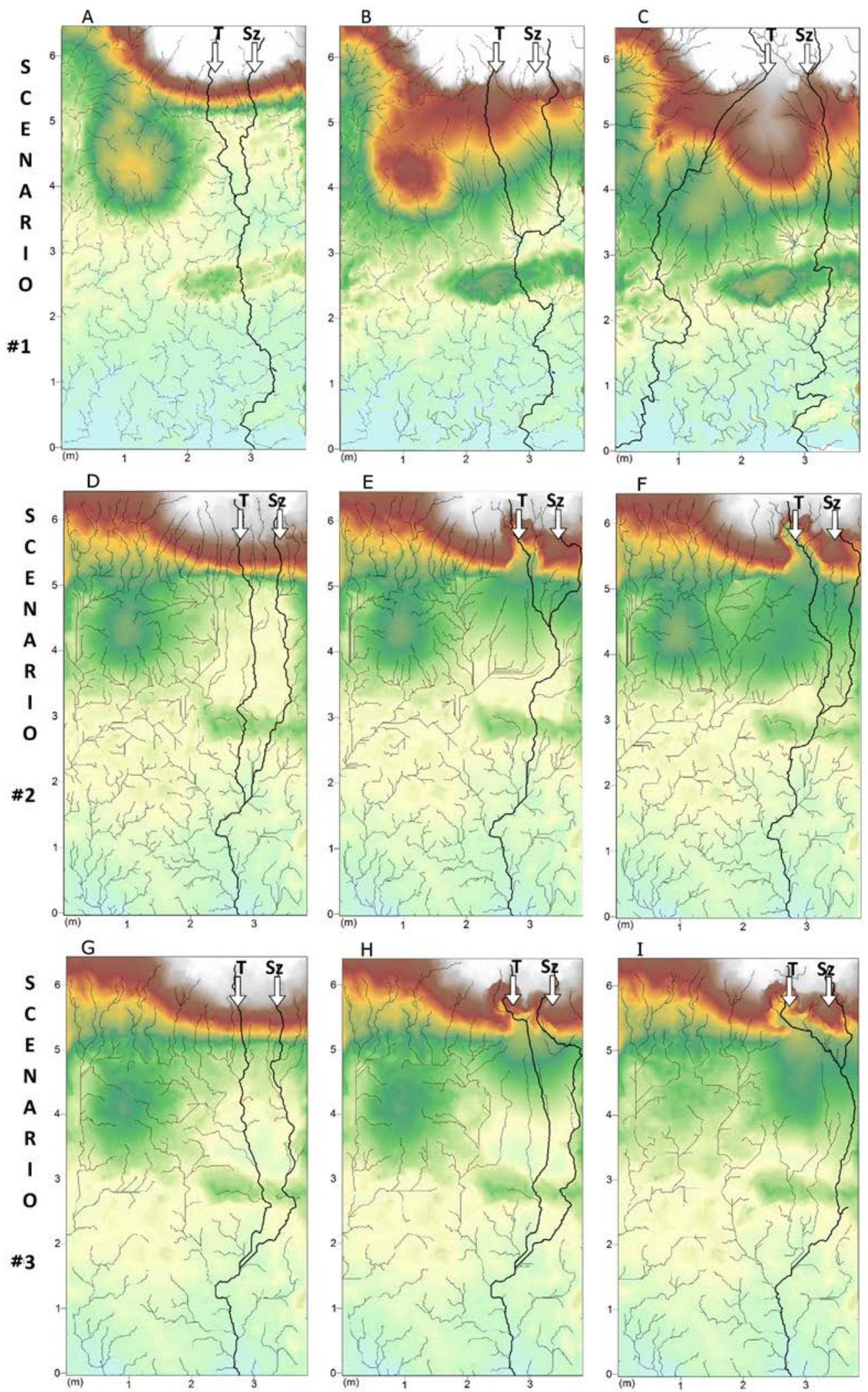

Fig. 5: Possible flow directions calculated from the DSMs in each stage of the Scenarios. T - Tisza River; Sz - Szamos River 

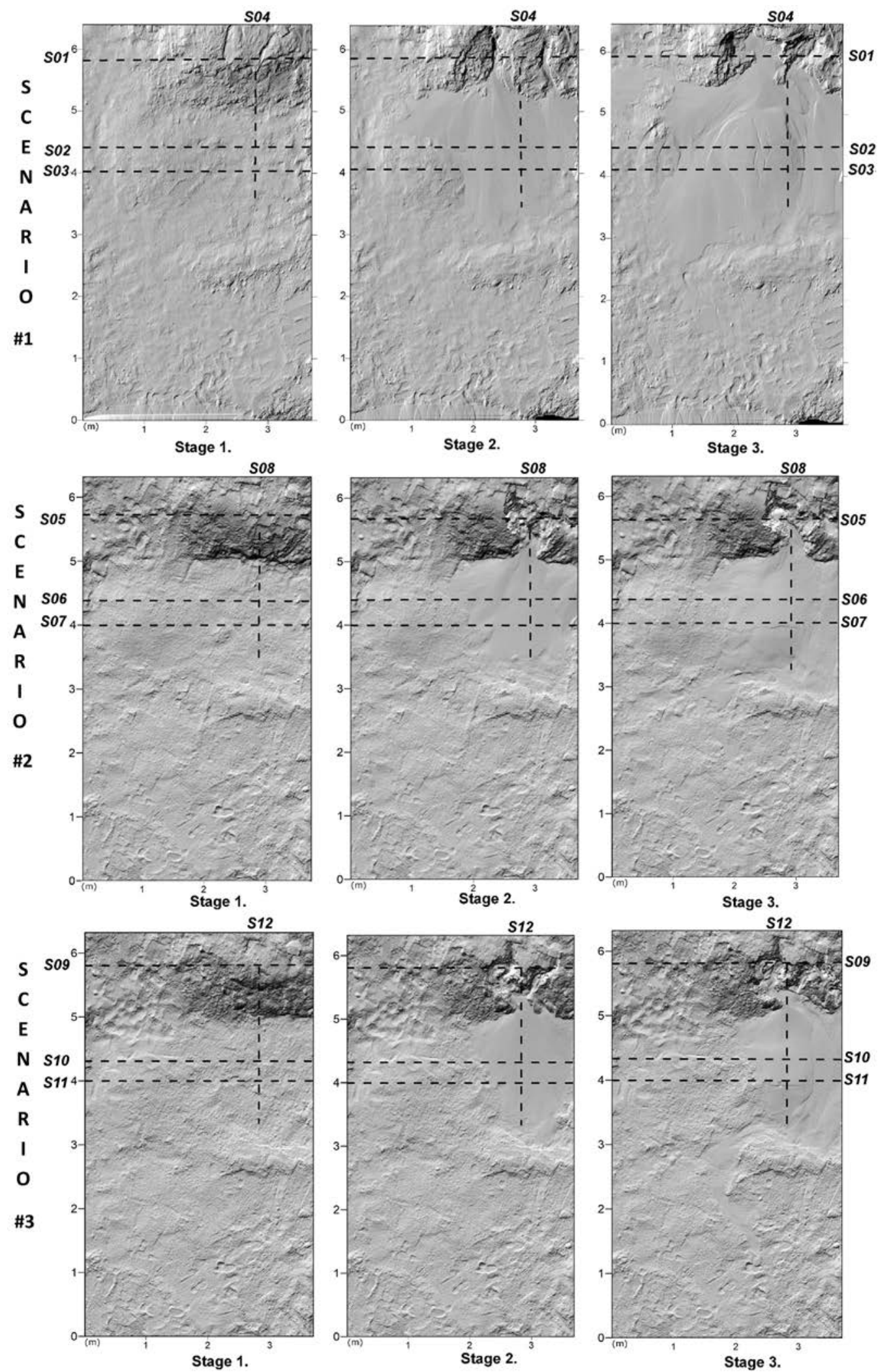

Fig. 6: Cross-sectional analysis of the experiment stages 


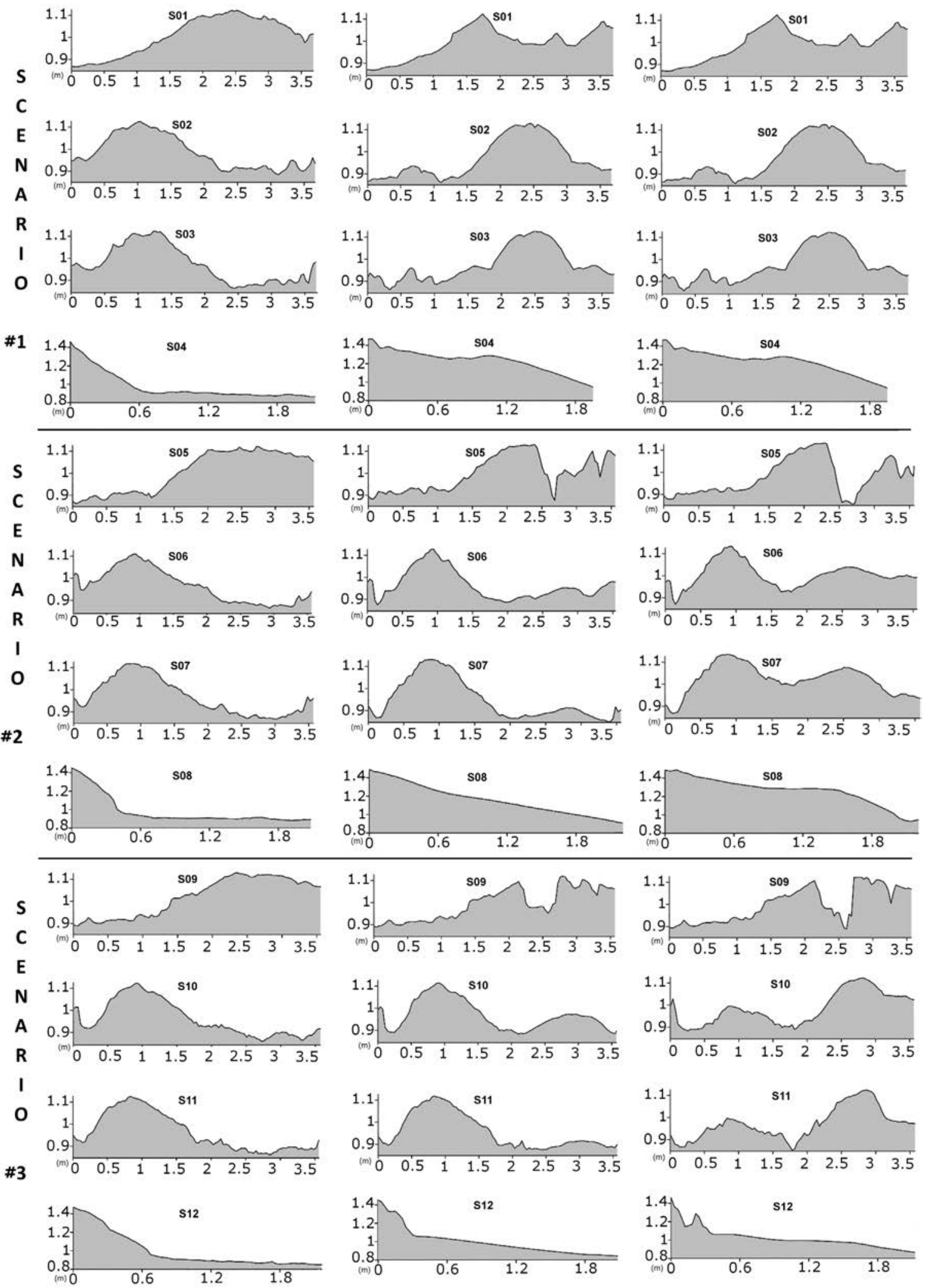

Fig. 7: Cross-sectional analysis of the experiment stages 
$15 \mathrm{~cm}$ horizontally) on the surface so as to fill the lower parts of the plain area. A Hillshade model (Fig. 5/B,C,E,F; Fig. 6; Fig. 7.) can provide evidence that the main flow direction of the Tisza River faced towards the Érmellék especially after a minor secondary alluvial fan also formed at the western side after the central plain region had filled up with sediments.

Following the second stage, we performed the tectonic operations for Scenario \#1 in two stages. First, we started the slow uplift of the central Nyírség alluvial fan with the rate of $0.02 \mathrm{~cm} / \mathrm{s}$. Afterwards, we simultaneously implemented the intensive sinking $(0.1 \mathrm{~cm} / \mathrm{s})$ of the Bodrogköz area, then we maintained these conditions until the end of the stage so as to reproduce a similar process of the theory. The uplift and sinking rates were calculated as the ratio of the height difference and the time elapsed during the scenario, since we had no instrument to measure their exact velocities. According to the cross section analysis the tectonic uplift rate of the Nyírség alluvial fan was about $16-18 \mathrm{~cm}$ while the sinking rate of Bodrogköz was about 14-16 cm (Fig. 6/S02-S03). By the end of the experiment, as a result of these operations the avulsion of the Tisza River occurred abruptly towards the western part of the flume after the sinking of Bodrogköz (Fig. 4/C; Fig. 5/C) similarly to the assumed concept; however, the Szamos River did not collide into the Tisza River (the streambed shift was measured to be approximately $1.1 \mathrm{~m}$ horizontally; Fig. 5).

In the first modified scenario (Scenario \#2) we omitted the sinking process of the Bodrogköz area throughout the experiment. (Fig. 6/S06-S07). In Scenario \#3, the rate of sinking in the Bodrogköz area was less (about 10-12 cm, $0.01 \mathrm{~cm} / \mathrm{s}$ ) (Fig. 6/S10-S11), than it was in Scenario \#1, and we performed the tectonic uplift of the Nyírség alluvial fan intermittently up to $13-15 \mathrm{~cm}(0.014 \mathrm{~cm} / \mathrm{s})$ during the last stage of the experiment; however, it reached almost the same height as was measured in Scenario \#1 $(16-18 \mathrm{~cm})$. By the end of the modified scenario-based experiments, none of the modified scenarios resulted in the avulsion of the Tisza River, because it remained at the eastern side of the Nyírség alluvial fan.

\section{Discussion}

The flow direction modelling revealed that the main flow direction of the Tisza River was approximately straight along the Nyírség alluvial fan; however, minor flows were able to reach the western parts (Fig. 5/B). Thus, a slight shifting to the west- ern side of the alluvial fan had started which fits to the theory of Borsy (1989) as the flow of the Tisza River came to a higher position because of the development of the Nyírség alluvial fan, and started to leave its central area (Fig. 8/1 proved). Since the alluvial fan extended to the Bodrogköz area, it inhibited the Tisza River from flowing towards the western part of the flume for a while during this stage.

The second stage of the scenarios resulted in a major alluvial fan of the Tisza River and minor fans (Fig. 4/B; Fig. 5/B) related to the Szamos River as Borsy $(1961,1964)$ and Borsy et al. $(1969,1989)$ described it earlier (Fig. $8 / 2$ proved). At the end of the second stage in Scenario \#1, we performed the vertical tectonic processes which resulted in surface conditions similar to those described previously (BORsY et al. 1989; Demeter et al. 2010, 2011; GÁBris 2002; Timár et al. 2005; LóKI and FÉLEgYHÁzi 2008; Kiss et al. 2014). The comparison between the theoretical avulsion process of the Tisza River assumed by TimÁr et al. (2005) and the result of the experimental approach showed several similarities (Fig. 5/C; Fig. 9). At the end of the experiment slight runoffs reached the Érmellék region, but the emerged Nyírség alluvial fan became a watershed divide (Fig. 5/C), which then diverted the significant part of the flows towards the western part of the flume. However, a few minor flows remained at the eastern part, as Kiss et al. (2012, 2014) and LóKI et al. (1994) have already suggested. Furthermore, we noticed that the Szamos River did not become a tributary of the Tisza River after the avulsion of the Tisza River (Fig. 5/C; Fig. 9). It was observed by other studies that avulsion occurs when i.e. a pre-existing abandoned channel can be reached easily (Aslan and Blum 1999; Slingerland and Smith 2004) or if the channels are elevated enough to collide (ZARN and Davies 1994; Mohrig et al. 2000; Field 2001; Cazanacli et al. 2002; Jerolmack and Paola 2007). In this case, the Nyírség alluvial fan was overly elevated only in Scenario \#1, and therefore the channel of the Szamos River was not able to reach the Tisza River and potentiate the avulsion process, while the former alternating channels had been already accumulated (Fig. 8/4 partially proved).

We have also examined the differences that resulted from the modified settings of Scenarios \#2 and \#3. In Scenario \#2 narrow secondary flow paths from the direction of the mountainous region had been formed, but the tectonic sinking process of the Bodrogköz region had been totally omitted. This process lacking connections among these nar- 


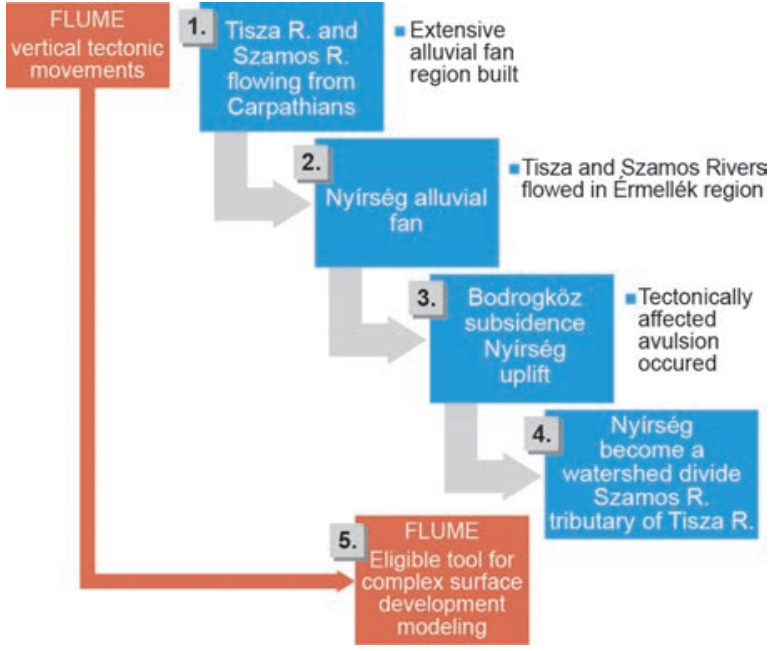

Fig. 8: Flow chart representing the theoretical background of our flume experiments

row channels, caused the main channel of paleoTisza to incise towards the eastern part of the flume. It appears that, with an increased uplift, the direction of the Tisza River could have been also turned towards the western part. However, in this case the distance of the Tisza River and the Nyírség alluvial fan was smaller than described by Borsy (1989).In other words, streambed shifting (i.e. avulsion) of the Tisza River was able to show a two times less rate (Fig. 5/E,F).

Scenario \#3 demonstrated an intermittent tectonic uplift process of the Nyírség alluvial fan and a moderate sinking of the Bodrogköz area. These movements collectively resulted in a continuous shifting of the streambed eastwards (Fig. 5/H,I). This can be explained by the discontinuous slow uplift inhibiting displacements westwards.
The two modified scenarios, where the subsidence of the Bodrogköz area was skipped or the subsidence rate was more moderate, both pointed out that, without this type of tectonic sinking, the Tisza River would had been able to change its path towards the western part of the plain if the tectonic uplift of the Nyírség alluvial fan would had been more intensive. This differs from the theory of Borsy (1989), who described the sinking Bodrogköz area as a necessary condition for the avulsion of the Tisza River.

Since it is not possible to remodel the original spatial conditions of the surface during the Late Pleistocene accurately, our experimental surface development scenario is not a topographically exact reconstruction of the natural process that occurred at the GHP related to the Tisza River. However, we demonstrated the main characteristic processes that could serve as evidence for already published former conceptions (BORSY et al. 1989; TIMÁr et al. 2005; GÁBRIS and NÁDOR 2007). The combination of different types of experimental methods in one flume enabled us to simulate the evolution of large alluvial fans of the Tisza River and Szamos River, among which the most extensive one, the Nyírség area, played an important role in the avulsion process. The tectonic uplift of the Nyírség proved to be the determining factor for the abrupt channel change of the Tisza River, while the previously suggested essential role of the Bodrogköz area has to be questioned (Fig. 8/3 partially proved).

Though several other studies (LisLE et al. 1991; SMith 1998; RÜTHer and Olsen 2007; VAn DijK et al. 2009, 2012) already proved that simple flumes can be used to investigate separate processes, we still had to carry out a new methodological development for the flume of our extended purpose. Originally, the flume did not contain any possibility for tectonic modelling, but our device was re-designed specifically for this pur-
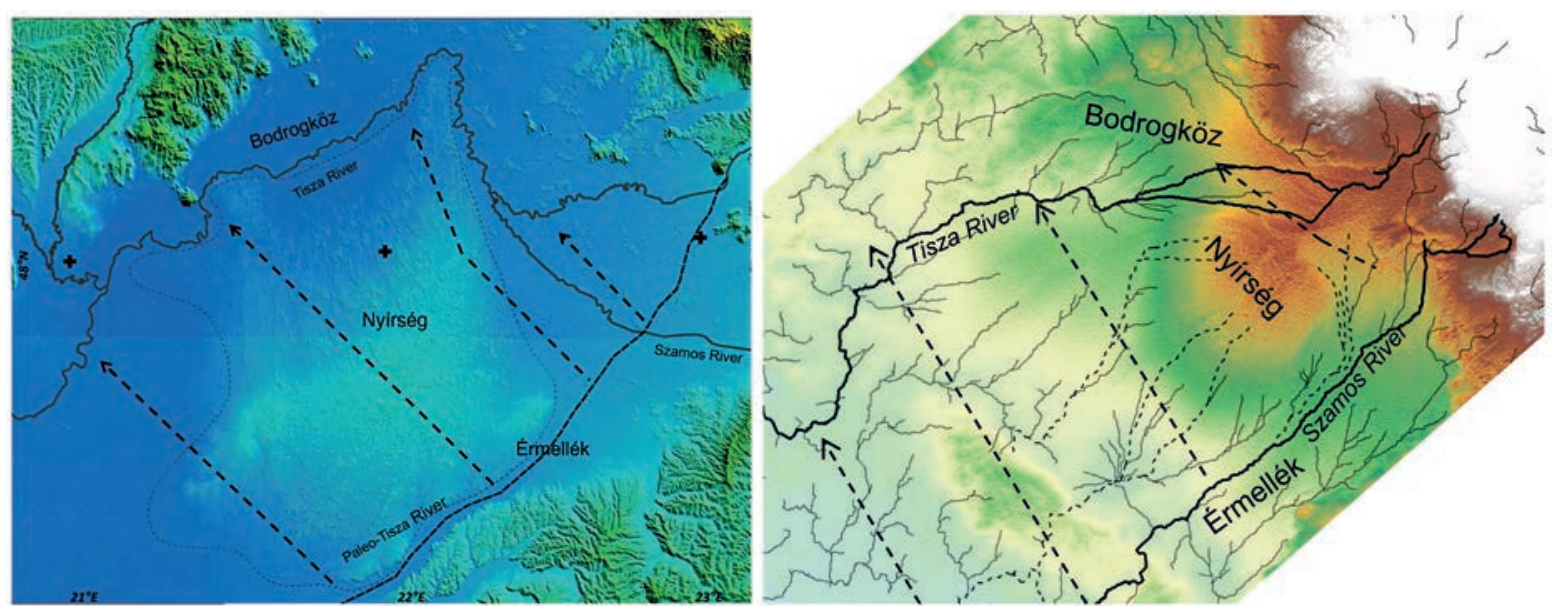

Fig. 9: Comparison of the theoretical and experimental approaches 
pose. It was important to vary the elevation of the different surface sections in a short distance: while one part was uplifted, the other had to move downwards. Finally, as we were able to reconstruct the paleo-processes and the result corresponded with each stage of the theory and the current surface, we proved that flume experiments can be suitable for the reconstruction of surface development theories taking into account several landscape forming processes (alluvial fan development, tectonic uplifts, discharge) simultaneously. In the case of the Tisza River, by using a flume, and the appropriate equipment, we were able to justify surface development processes in mesoscale (ca. 32,000 km²) (Fig. 8/5 proved). In addition, by designing new supplementary functions to this flume, the instrument can be used for practical applications i.e. more complex reconstruction of the Great Hungarian Plain could help in modeling the possible locations of water resources that could be connected with present hydrocarbon sites of the area as well.

\section{Conclusion}

Previous studies have shown several uncertainties related to the theoretical descriptions of the fluvial system evolution and surface development of the GHP. As a refinement, the complex progress of fluvial surface development, including an avulsion, alluvial fan development and tectonic uplifts/subsidences at an alluvial part of the GHP have been investigated using a new methodological approach in a flume experiment.

In contrast to flume-based studies which focus on only one selected process, we performed an experiment that was able to confirm several parts of a multiple alluvial plain development theory. However, the three-stage flume experiment was not a topographically accurate reconstruction; rather, we confirmed the importance of the Nyírség alluvial fan and its tectonic uplift in the abrupt avulsion process of the Tisza River as it came to be a natural divide.

\section{Acknowledgements}

We would like to thank Dr. Joan Plubell Mattia for proofreading the manuscript. This work was supported by the University of Debrecen (RH/751/2015). The publication was supported by the SROP-4.2.2.B-15/1/ KONV-2015-0001 project. The project has been supported by the European Union, co-financed by the European Social Fund. The research was supported by long-term conceptual development support of re- search organisation (Institute of Geonics of the Czech Academy of Sciences) RVO: 68145535.

\section{References}

ACKERS, P. (1964): Experiments on small streams in alluvium. In: Journal of Hydraulics Division, American Society of Civil Engineers 90 (4), 1-37.

Aslan, A. and Blum, M. D. (1999) Contrasting styles of Holocene avulsion, Texas Gulf Coastal Plain, USA. In: SмrтH, N. D. and Rogers, J. (eds.): Fluvial sedimentology VI. Oxford, 193-209. DOI: 10.1002/9781444304213.ch15

BenNeTt, S. J. and BRIDGE, J. S. (1995): An experimental study of flow, bedload transport and bed topography under conditions of erosion and deposition and comparison with theoretical models. In: Sedimentology 42, 117-146. DOI: 10.1111/j.1365-3091.1995.tb01274.x

BeVEN, K. J. and KIRKBY, M. J. (1979): A physically based variable contributing-area model of catchment hydrology. In: Hydrological Science Bulletin 24 (1), 43-69. DOI: 10.1080/02626667909491834

Borsy, Z. (1961): A Nyírség természeti földrajza. (The physical geographical overview of the Nyírség) - Földrajzi monográfiák (Geographical Monographs). Akadémiai Kiadó. Budapest (In Hungarian)

Borsy, Z. (1964): A Nyírség geomorfológiai kutatásának gyakorlati vonatkozású eredményei (The practical relevance of the results from geomorphological research in the Nyírség). In: Földrajzi Közlemények (Geographical Review) 1964 (4), 293-308. (In Hungarian)

Borsy, Z. (1989): Az Alföld hordalékkúpjainak negyedidőszaki fejlődéstörténete (Quaternary evolution of the alluvial fans of Great Hungarian Plain). In: Földrajzi Értesítő (Hungarian Geographical Bulletin), 211-224. (In Hungarian)

Borsy, Z. (1990): Evolution of the alluvial fans of the Alföld. In: RACHOCKI, A. H. and CHURCH, M. (eds.): Alluvial fans - a field approach. Hoboken, 229-248.

Borsy, Z. (1995): Evolution of the north-eastern part of the Great Hungarian Plain in the past 50000 years. In: Questiones Geographicae, Special Issue 4, 65-71.

Borsy, Z. and FÉlEgYHÁZI, E. (1983): Evolution of the network of water courses in the north-eastern part of the Great Hungarian Plain from the end of the Pleistocene to our days. In: Quaternary Studies in Poland 4, 115-124.

Borsy, Z.; Molnár, B. and SOMOGYI, S. (1969): Alluviális medencesíkságok morfológiai fejlődéstörténete (Morphological evolution of alluvial plains). In: Földrajzi Közlemények (Geographical Review) 1969 (3), 237-254. (In Hungarian)

Borsy, Z.; FélegyHÁzi, E. and Csongor, É. (1989): A Bodrogköz kialakulása és a vízhálózatának változásai (Evolution of the Bodrogköz and changes in its drainage system). In: Alföldi Tanulmányok, 65-81. (In Hungarian) 
Cazanacli, D.; Paola, C. and Parker, G. (2002): Experimental steep braided flow: application to flooding risk on fans. In: Journal of Hydrological Engineering 128, 1-9. DOI: 10.1061/(ASCE)0733-9429(2002)128:3(322)

Clarke, L.; Quine, T. A.; Nicholas, A. (2010): An experimental investigation of autogenic behaviour during alluvial fan evolution. In: Geomorphology 115, 278-285. DOI: 10.1016/j.geomorph.2009.06.033

Conrad, O.; Bechtel, B.; Bock, M.; Dietrich, H.; Fischer, E.; Gerlitz, L.; Wehberg, J.; Wichmann, V. and BoehNER, J. (2015): System for automated geoscientific analyses (SAGA) v. 2.1.4. In: Geoscientific Model Development 8, 1991-2007. DOI: 10.5194/gmd-8-1991-2015

Coulthard, T. J.; Kirkby, M. J. and Macklin, M. G. (1999): Modelling the impacts of Holocene environmental change on the fluvial and hillslope morphology of an upland landscape, using a cellular automaton approach. In: Brown, A. G. and Quine, T. M. (eds.): Fluvial processes and environmental change. Chichester; 31-47.

Coulthard, T. J.; Macki.j, M. G. and Kirkby, M. J. (2002): A cellular model of Holocene upland river basin and alluvial fan evolution. In: Earth Surface Processes and Landforms 27, 269-288. DOI: 10.1002/esp.318

Demeter, G.; PüspöKI, Z.; LazÁnyi, I. and Buday, T. (2010): Szekvencia-sztratigráfiai alapú földtani kutatás Nyíregyháza-Szatmárnémeti térségében (Sequence stratigraphy based geological research in the Nyíregyháza-Szatmárnémeti region). Dominium Kiadó, Miskolc. (In Hungarian)

Demeter, G.; Tóthné, M. Á.; Buday, T. and Püspöki Z. (2011): A nyírségi pleisztocén hordalékkúp fejlődéstörténete és őskörnyezeti rekonstrukciója (Evolutionary and palaeoenvironmental reconstruction of the Pleistocene alluvial fan of Nyírség). In: RAKONCZAI, J. (ed.) Környezeti változások és az Alföld. Nagyalföld Alapítvány (A Nagyalföld Alapítvány Kötetei; 7.), Békéscsaba, 283-295. (in Hungarian)

Douglass, J. and SchmeEckle, M. (2007): Analogue modeling of transverse drainage mechanisms. In: Geomorphology 84, 22-43. DOI: 10.1016/j.geomorph.2006.06.004

Egozi, R. and Ashmore, P. (2009): Experimental analysis of braided channel response to increased discharge. In: Journal of Geophysical Research - Earth Surface 114, F02012. DOI: 10.1029/2008JF001099

FÉlegyházi, E.; Szabó, J.; SzÁntó, Z. and Tóth, C. (2004): Adalékok az északkelet-Alföld pleisztocén végi, holocén felszínfejlődéséhez újabb vizsgálatok alapján. (Late Pleistocene and Holocene evolution of NE Great Plain) II. MFK Szeged, 1-10. (In Hungarian)

FIELD, J. (2001): Channel avulsion on alluvial fans in southern Arizona. In: Geomorphology 37, 93-104. DOI: 10.1016/ S0169-555X(00)00064-7

FrIEDKIN, J. F. (1945): A laboratory study of the meandering of alluvial rivers. Vicksburg.
GÁBRIS, G. (1986): Alföldi folyóink holocén vízhozamai. (Holocene discharge of the rivers of the Great Hungarian Plain). In: Alföldi Tanulmányok 10, 35-48. (In Hungarian)

- (1995): A folyóvízi felszínalakítás módosulásai a hazai későglaciális-holocén őskörnyezet változásainak tükrében (River activity as a function of changing palaeoenvironmental conditions during the Late Glacial-Holocene, Hungary). In: Földrajzi Közlemények 119, 3-10. (In Hungarian)

- (2002): A Tisza helyváltozásai (The shifting of Tisza River). In: MészÁros, R.; Schweitzer, F. and Tóth, J. (eds.): Jakucs László, a tudós. MTA-FKI Pécs, 91-105. (In Hungarian)

GÁBrIs, G. and NÁDOR, A. (2007): Long-term fluvial archives in Hungary: response of the Danube and Tisza rivers to tectonic movements and climatic changes during the Quaternary: a review and new synthesis. In: Quaternary Science Reviews 26, 2758-2782. DOI: 10.1016/j.quascirev.2007.06.030

Gábris, G.; Horváth, E.; Novothny, A. and RuszKICZAY-RÜDIGER, Z. (2012): Fluvial and aeolian landscape evolution in Hungary - results of the last 20 years research. In: Netherlands Journal of Geosciences 91, 111128. DOI: $10.1017 /$ S0016774600001530

GilberT, G. K. (1914): The transportation of debris by running water. US Geological Survey Professional Paper 86. Washington, DC.

Graveleau, F.; Hurtrez, J.-E.; Dominguez, S. and MalavieILLE, J. (2011): A new experimental material for modeling relief dynamics and interactions between tectonics and surface processes. In: Tectonophysics 513, 68-87. DOI: 10.1016/j.tecto.2011.09.029

Guy, H. P.; Simons, D. B. and Richardson, E. V. (1966): Summary of alluvial channel data from flume experiments, 1956-1961. US Geological Survey Professional Paper 462-I. Washington, DC.

Hickin, E. J. (1972): Pseudomeanders and point dunes; a flume study. In: American Journal of Science 272, 762799. DOI: 10.2475 /ajs.272.8.762

Hooke, R. L. and Rohrer, W. L. (1979): Geometry of alluvial fans: effect on discharge and sediment size. In: Earth Surface Processes 4, 147-166.

HowARD, A. D. (1994): A detachment limited model of drainage basin evolution. In: Water Resources Research 30 (7), 2261-2285. DOI: 10.1029/94WR00757

Jerolmack, D. J. and Paola, C. (2007): Complexity in a cellular model of river avulsion. In: Geomorphology 91, 259-270. DOI: 10.1016/j.geomorph.2007.04.022

KÁDÁr, L.; Borsy, Z. and KoczKA, K. (1957): A Debreceni Kossuth Lajos Tudományegyetem Földrajzi Intézetének folyóvizes terepasztala (The experimental flume of the Institute of Geography at Kossuth Lajos University Debrecen). In: Földrajzi Közlemények (Geographical Review) 1956 (3), 263-273. (In Hungarian) 
KinOSHITA, R. (1957): Formation of dunes on river beds - an observation on the condition of meandering. In: Proceedings of the Japanese Society of Civil Engineers 42, 1-21.

Kiss, T.; Siros, G.; Mauz, B. and MezősI, G. (2012): Holocene aeolian sand mobilization, vegetation history and human impact on the stabilized sand dune area of the southern Nyírség, Hungary. In: Quaternary Research 78, 492-501. DOI: $10.1016 /$ j.yqres.2012.07.002

Kiss, T.; Hernesz, P.; Sümeghy, B.; GyÖrgyövics, K. and Sipos, G. (2014): The evolution of the Great Hungarian Plain fluvial system - Fluvial processes in a subsiding area from the beginning of the Weichselian. In: Quaternary International 388, 142-155. DOI: 10.1016/j.quaint.2014.05.050

Lague, D.; Crave, A. and Davy, P. (2003): Laboratory experiments simulating the geomorphic response to tectonic uplift. In: Journal of Geophysical Research - Solid Earth 108 (B1), ETG 3-1-ETG 3-20. DOI: 10.1029/2002JB001785

LANZONI, S. (2000): Experiments on bar formation in a straight flume, 1. Uniform sediment. In: Water Resources Research 36 (11), 3337-3349. DOI: 10.1029/2000WR900160

Le Coz, J.; Michalková, M.; Hauet, A.; Comaj, M.; Dramais, G.; Holubová, K.; Piégay, H. and Paquier, A. (2010): Morphodynamics of the exit of a cutoff meander: experimental findings from field and laboratory studies. In: Earth Surface Processes and Landforms 35, 249-261. DOI: 10.1002/esp.1896

Leopold, L. B. and Wolman, M. G. (1957): River channel patterns: braided, meandering and straight. Geological Survey Professional Paper 282 B. Washington, DC.

Lisle, T. E.; IkEDA, H.; IsEYA F. (1991): Formation of stationary alternate bars in a steep channel with mixed-size sediment: a flume experiment. In: Earth Surface Processes and Landforms 16, 463-469.

LókI, J. and FÉLEgYHÁzI, E. (2008): A Bodrogköz kialakulása és mai felszíne (The development and recent surface of Bodrogköz). In: TuBA, Z. (ed.): Bodrogköz (A magyarországi Bodrogköz tájmonográfiája), Lorántffy Zsuzsanna Szellemében Alapítvány. Sárospatak, 99-123. (In Hungarian)

Lóki, J.; Hertelend, E. and Borsy, Z. (1994): New dating of blown sand movement in the Nyírség. In: Acta Geographica ac Geologica et Meteorologica Debrecina 32, 67-76.

Marra, W. A.; Braat, L.; BaAr, A. W. and Kleinhans, M. G. (2014): Valley formation by groundwater seepage, pressurized groundwater outbursts and crater-lake overflow in flume experiments with implications for Mars. In: Icarus 232, 97-117. DOI: 10.1016/j.icarus.2013.12.026

McKenna Neuman, C. L.; Ashmore, P. and Bennett, S. (2013): Laboratory and experimental geomorphology: examples from fluvial and aeolian systems. In: SHroder, J. F. (ed.) Treatise on geomorphology Vol. 1, 325-348. San Diego. DOI: 10.1016/b978-0-12-374739-6.00017-8

MezôsI, G. (2011): Magyarország természetföldrajza (Physical Geography of Hungary). Akadémiai Kiadó, Budapest. (In Hungarian)
Mohrig, D. C.; Heller, P. L.; Paola, C. and Lyons, W. J. (2000): Interpreting avulsion process from ancient alluvial sequences: Guadalope-Matarranya system (northern Spain) and Wasatch Formation, (western Colorado). In: Geological Society of America Bulletin 112 (12), 1787-1803. DOI: 1130/0016-7606(2000)112<1787:IAPFAA >2.0.CO;2

Muto, T. and Steel, R. (2001): Autostepping during the transgressive growth of deltas: results from flume experiments. In: Geology 29 (9), 771-774. DOI: 091-7613(2001)029<0771:ADT'TGO>2.0.CO;2

- (2004): Autogenic response of fluvial deltas to steady sea-level fall: implications from flume-tank experiments. In: Geology 32 (5), 401-404. DOI: 10.1130/G20269.1

Nicholas, A. P. and Quine, T. A. (2007a): Crossing the divide: representation of channels and processes in reduced-complexity river models at reach and landscape scales. In: Geomorphology 90, 318-339. DOI: 10.1016/j. geomorph.2006.10.026

- (2007b): Modelling alluvial landform change in the absence of external environmental forcing. In: Geology 35, 527530. DOI: $10.1130 / \mathrm{G} 23377 \mathrm{~A} .1$

Okura, Y.; Kitahara, H.; Ochiai, H.; Sammori, T. and KaWaNAMI, A. (2002): Landslide fluidization process by flume experiments. In: Engineering Geology 66, 65-78. DOI: 10.1016/S0013-7952(02)00032-7

Ouchi, S. (1985): Response of alluvial rivers to slow active tectonic movement. In: Geological Society of America Bulletin 96 (4), 504-515. DOI: 0/0016-7606(1985)96<504:ROARTS>2.0.CO;2

Paola, C.; Straub, K.; Mohrig, D. and Reinhardt, L. (2009): The "unreasonable effectiveness" of stratigraphic and geomorphic experiments. In: Earth Science Reviews 97, 1-43. DOI: 10.1016/j.earscirev.2009.05.003

Parker, G.; Paola, C.; Whipple, K. X. and Mohrig, D. C. (1998): Alluvial fans formed by channelized fluvial and sheet flow: I: Theory. In: Journal of Hydraulic Engineering 124, 985-995. DOI: 10.1061/(ASCE)07339429(1998)124:10(985)

Peakali, J.; Ashworth, P. J. and Best, J. L. (1996): Physical modelling in fluvial geomorphology: principles, applications and unresolved issues. In: RHOADs, B. and THORN, C. (eds.): The scientific nature of geomorphology. Chichester, 222-253.

Peakall, J.; Ashworth, P. J. and Best, J. L. (2007): Meander-bend evolution, alluvial architecture, and the role of cohesion in sinuous river channels: a flume study. In: Journal of Sedimentary Research 77, 197-212. DOI: 10.2110/jsr.2007.017

Pirkhoffer, E.; Halmai, Á.; Czigány, S.; Bugya, T.; Rábay A.;

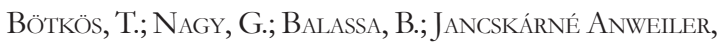
I. and Lóczy, D. (2014): New opportunities for experiments in fluvial geomorphology: the flume PTETHYS. In: Hungarian Geographical Bulletin 63 (4), 425-436. DOI: 10.15201/hungeobull.63.4.4 
Postma, G.; Kleinhans, M. G.; Meijer, P. T.; EggenhuISEN, J. T. (2008): Sediment transport in analogue flume models compared with real-world sedimentary systems: a new look at scaling evolution of sedimentary systems in a flume. In: Sedimentology 55, 1541-1557. DOI: 10.1111/j.1365-3091.2008.00956.x

RÜTHER, N. and OlsEn, N. R. B. (2007): Modelling free-forming meander evolution in a laboratory channel using three-dimensional fluid dynamics. In: Geomorphology 89, 308-319. DOI: 10.1016/j.geomorph.2006.12.009

Schumm, S. A. and KHAN, H. R. (1972): Experimental study of channel patterns. In: Geological Society of America Bulletin 83 (6), 1755-1770. DOI: 10.1130/0016-7606(1972)83[1755:ESOCP]2.0.CO;2

Schumm, S. A.; Mosely, M. P. and Weaver, W. E. (1987): Experimental fluvial geomorphology. New York

SмiтH, C. E. (1998): Modeling high sinuosity meanders in a small flume. In: Geomorphology 25, 19-30. DOI: 10.1016/S0169-555X(98)00029-4

Slaymaker, O. (ed.) (1991): Field experiments and measurement program in geomorphology. Vancouver

Slingerland, R. and Smith, N. D. (2004): River avulsions and their deposits. In: Annual Review of Earth and Planetary Sciences 32, 257-285. DOI: 10.1146/annurev. earth.32.101802.120201

Somogyi, S. (1961): Hazánk folyóhálózatának fejlődéstörténeti vázlata (Development of the Hungarian fluvial system). In: Földrajzi Közlemények 9, 25-50. (In Hungarian)

SzABÓ, J.; VAss, R. and Tóth, C. (2012): Examination of fluvial development on study areas of Upper-Tisza region. In: Carpathian Journal of Earth and Environmental Sciences 7 (4), 241-253.

Termini, D. and Piraino, M. (2011): Experimental analysis of cross-sectional flow motion in a large amplitude meandering bend. In: Earth Surface Processes and Landforms 36 (2), 244-256. DOI: 10.1002/esp.2095

Thorndycraft, V. R.; Benito, G. and Gregory, K. J. (2008): Fluvial geomorphology: a perspective on current status and methods. In: Geomorphology 98, 2-12. DOI: 10.1016/j.geomorph.2007.02.023

Timár, G.; Sümegi, P. and Horváth, F. (2005): Late Quaternary dynamics of the Tisza River: evidence of climatic and tectonic controls. In: Tectonophysics 410, 97-110. DOI: $10.1016 /$ j.tecto.2005.06.010

Van Dijk, M.; Postma, G. and Kleinhans, M. G. (2009): Autocyclic behaviour of fan deltas: an analogue experimental study. In: Sedimentology 56, 1569-1589. DOI: 10.1111/j.1365-3091.2008.01047.x

Van Dijk, W. M.; van de Lageweg, W. I. and Kleinhans, M. G. (2012): Experimental meandering river with chute cutoffs. In: Journal of Geophysical. Research 117, F03023. DOI: 10.1029/2011JF002314
VAss, R.; Szabó, G. and Szabó, J. (2010): Examination of sedimentary deposition in the active floodplains of Bereg plain. In: Studia Universitatis Vasile Goldis Arad - Seria Stiintele Vietii (Life Sciences Series) 20 (4), 105-110.

Viseras, C.; Calvache, M. L.; Soria, J. M. and Fernandez, J. (2003): Differential features of alluvial fans controlled by tectonic or eustatic accommodation space: examples from the Betic Cordillera, Spain. In: Geomorphology 50, 181-202. DOI: 10.1016/S0169-555X(02)00214-3

Whipple, K. X.; Parker, G.; Paola, C. and Mohrig, D. C. (1998): Channel dynamics, sediment transport and the slope of alluvial fans: experimental study. In: Journal of Geology 106, 677-693. DOI: 10.1086/516053

Williams, G. P. (1971): Aids in designing laboratory flumes. USGS Openfile report 71-327. http://pubs.usgs.gov/ of/1971/0327/report.pdf

Wolman, M. G. and Brush, L. M. (1961): Factors controlling the size and shape of stream channels in coarse noncohesive sands. In: United States Geological Survey Professional Paper 282 G, 183-210. Washington, DC.

Zarn, B. and Davies, T. R. (1994): The significance of processes on alluvial fans to hazard assessment. In: Zeitschrift fur Geomorphologie 38, 487-500.

\section{Authors}

László Bertalan

Dr. Csaba A. Tóth

Dr. Gergely Szabó

Dr. Szilárd Szabó

Department of Physical Geography and Geoinformatics University of Debrecen

Egyetem tér 1. 4032

Debrecen

Hungary

bertalan@science.unideb.hu

Gábor Nagy

Institute of Geoinformatics

Óbuda University

Alba Regia Technical Faculty

Pirosalma u. 1-3., 8000

Székesfehérvár

Hungary

František Kuda

Institute of Geonics

Czech Academy of Sciences

Drobného 28, 60200

Brno

Czech Republic 